\section{Hygienic quality of different forages and concentrates for horses}

\author{
Heike Sliwinsky? ${ }^{7}$ Peter Krabisch², Ewald Rosenberger ${ }^{3}$ \\ and Frieder J. Schwarz'
}

Department of Animal Science, Division of Animal Nutrition, Technical University of Munich, Freising-Weihenstephan', Bavarian Animal Health Service, Poing ${ }^{2}$ and Bavarian State Research Center for Agriculture, Institute of Animal Breeding, Poing ${ }^{3}$

\section{Introduction}

Horses are particularly sensitive to the hygienic quality of their feed due to the anatomical and physiological peculiarities of their digestive tract (Meyer and Coenen 2002) and also due to the great importance of their respiratory system for performance. Hygienic quality can be affected by contamination with soil particles, dust etc, but also by the microbial status, characterised by presence of bacteria, yeasts and mould spores. This investigation reports the microbial status of important common feedstuffs used in forty farms/stables where horses were kept.

\section{Materials and methods}

A total of 159 samples of different feedstuffs from 40 farms/stables were analysed. Three samples were taken of each individual component of rations, in intervals of 4 weeks, and kept at $2^{\circ} \mathrm{C}$ until the end of the sampling period, when they were combined. Each combined sample was homogenised and series of different strength dilutions were produced. These were applied in a spiral plate apparatus each to a rotating plate-count-agar plate (Merck 1.05463), a water blue-metachrome yellow-lactose-(WML)-agar plate (Gassner, Oxoid CM 431), a Sabouraud-dextrose-agar plate (Oxoid CM 41) and a malt extract agar plate. Quantitative evaluation was carried out by counting the colonies with the aid of a specially developed template. Qualitative evaluation was carried out after incubation at $30^{\circ}$ for 4 days, assessing the morphology of the colonies, and employing microscopic and biochemical criteria.

\section{Results}

The results were combined for all hays $\left(1^{\text {st }}\right.$ cut $n=41,2^{\text {nd }}$ cut $n=3)$ and all grass silages ( $1^{\text {st }}$ cut $n=9,2^{\text {nd }}$ and subsequent cuts $n=19$ ), while cereals and concentrate feeds were described separately. Tables 1 and 2 show the quantitative results of bacterial contamination and contamination with fungi (mould spores and yeasts). Using the classification criteria of Dresbach (1993) and Schmidt (1985), the feedstuffs were put in the categories "uncontaminated, normal", "increased contamination" and "greatly increased".

\section{Discussion}

As yet, there is no concrete framework for the categorisation of feedstuffs according to level of bacterial contamination. Therefore, only those results will be discussed where "greatly increased contamination" were found. Surprisingly few hay samples had microbial contamination. It is suggested that the weather
Table 1 Microbial assessment of the forages.

\begin{tabular}{|c|c|c|c|c|c|}
\hline $\begin{array}{l}\text { 1.Bacteria (aerobic, } n \\
(\text { Category) })^{1}\end{array}$ & $\begin{array}{c}\text { esophillic) (KBE/g) } \\
\leq 10^{7} \\
\text { ("normal") }\end{array}$ & $\begin{array}{l}>10^{7}-10^{9} \\
\text { ("increased") }\end{array}$ & $\begin{array}{l}\quad>10^{9} \\
(\text { ("greatly } \\
\text { increased") }\end{array}$ & & \\
\hline Hay $(n=44)$ & $\begin{array}{c}31 \\
(70 \%)\end{array}$ & $\begin{array}{c}9 \\
(20 \%)\end{array}$ & $\begin{array}{c}4 \\
(10 \%)\end{array}$ & & \\
\hline Grass silage $(n=26)$ & $\begin{array}{c}19 \\
(73 \%)\end{array}$ & $\begin{array}{c}7 \\
(27 \%)\end{array}$ & $\begin{array}{c}0 \\
(0 \%)\end{array}$ & & \\
\hline \multicolumn{6}{|l|}{ 2. Fungi (KBE/g) } \\
\hline (Category) $)^{1}$ & $\begin{array}{c}\leq 10^{5} \\
\text { (not detectable: } \\
2 * 10 \_ \text {and "normal") }\end{array}$ & $\begin{array}{l}\text { Moulds } \\
\qquad 10^{5}-10^{6} \\
\text { ("increased") }\end{array}$ & $\begin{array}{c}>10^{6} \\
\text { ("greatly } \\
\text { increased") }\end{array}$ & $\begin{array}{r}Y e \\
>10^{5}-10^{6} \\
\text { ("increased") }\end{array}$ & $\begin{array}{l}\text { sts } \\
\quad>10^{6} \\
\text { ("greatly } \\
\text { increased" }\end{array}$ \\
\hline Hay $(n=44)$ & $\begin{array}{c}42 \\
(96 \%)\end{array}$ & $\begin{array}{c}0 \\
(0 \%)\end{array}$ & $\begin{array}{c}0 \\
(0 \%)\end{array}$ & $\begin{array}{c}1 \\
(2 \%)\end{array}$ & $\begin{array}{c}1 \\
(2 \%)\end{array}$ \\
\hline Grass silage $(n=28)$ & $\begin{array}{c}7 \\
7 \\
(25 \%)\end{array}$ & $\begin{array}{c}2 \\
(7 \%)\end{array}$ & $\begin{array}{c}2 \\
(7 \%)\end{array}$ & $\begin{array}{c}4 \\
(14 \%)\end{array}$ & $\begin{array}{c}13 \\
(47 \%)\end{array}$ \\
\hline
\end{tabular}

'Categorisation according to Dresbach (2001)

Table 2 Microbial assessment of cereals and concentrates.

\begin{tabular}{|c|c|c|c|c|c|c|}
\hline & \multicolumn{3}{|c|}{ Bacteria (KBE/g) } & \multicolumn{3}{|c|}{$\begin{array}{c}\text { Moulds (KBE/g) } \\
1 \times 10^{4}\end{array}$} \\
\hline & $<2 \times 10^{6}$ & $1,2 \times 10^{7}$ & $>1,2 \times 10^{7}$ & $<1 \times 10^{4}$ & $-2 \times 10^{5}$ & $>2 \times 10^{5}$ \\
\hline$\left(\right.$ Category $^{1}$ & $\begin{array}{l}\text { ("normal, } \\
\text { fresh") }\end{array}$ & ("increased") & $\begin{array}{c}\text { ("greatly } \\
\text { increased") }\end{array}$ & ("normal") & ("increased") & $\begin{array}{c}\text { ("greatly } \\
\text { increased") }\end{array}$ \\
\hline Oats $(n=34)$ & $\begin{array}{c}2 \\
6 \%)\end{array}$ & $\begin{array}{c}10 \\
(30 \%)\end{array}$ & $\begin{array}{c}22 \\
(64 \%)\end{array}$ & $\begin{array}{c}8 \\
(24 \%)\end{array}$ & $\begin{array}{c}19 \\
(50 \%)\end{array}$ & $\begin{array}{c}7 \\
(20 \%)\end{array}$ \\
\hline Barley $(n=4)$ & $\begin{array}{c}4 \\
(40 \%)\end{array}$ & $\begin{array}{c}4 \\
(40 \%)\end{array}$ & $\begin{array}{c}2 \\
(20 \%)\end{array}$ & $\begin{array}{c}8 \\
(80 \%)\end{array}$ & $\begin{array}{c}2 \\
(20 \%)\end{array}$ & $\begin{array}{c}0 \\
(0 \%)\end{array}$ \\
\hline Maize $(n=9)$ & $\begin{array}{c}5 \\
(56 \%)\end{array}$ & $\begin{array}{c}1 \\
(11 \%)\end{array}$ & $\begin{array}{c}3 \\
(33 \%)\end{array}$ & $\begin{array}{c}9 \\
(100 \%)\end{array}$ & $\begin{array}{c}0 \\
(0 \%)\end{array}$ & $\begin{array}{c}0 \\
(0 \%)\end{array}$ \\
\hline $\begin{array}{l}\text { Concentrate home- } \\
\text { mix }(n=6)\end{array}$ & $\begin{array}{c}1 \\
(17 \%)\end{array}$ & $\begin{array}{c}3 \\
(50 \%)\end{array}$ & $\begin{array}{c}2 \\
(33 \%)\end{array}$ & $\begin{array}{c}6 \\
(100 \%)\end{array}$ & $\begin{array}{c}0 \\
(0 \%)\end{array}$ & $\begin{array}{c}0 \\
(0 \%)\end{array}$ \\
\hline bought in $(n=18)$ & $\begin{array}{c}9 \\
(50 \%)\end{array}$ & $\begin{array}{c}4 \\
(22 \%)\end{array}$ & $\begin{array}{c}5 \\
(28 \%)\end{array}$ & $\begin{array}{c}17 \\
(94 \%)\end{array}$ & $\begin{array}{c}1 \\
(6 \%)\end{array}$ & $\begin{array}{c}0 \\
(0 \%)\end{array}$ \\
\hline
\end{tabular}

'Categorisation according to Schmidt (1985)

conditions in different years are of paramount importance for hygienic quality. Some grass silages showed high levels of yeasts, and this leads to a call for evaluating the classification scheme. The results also suggest that the method of getting silage from the silo or the speed with which a silo or big bale is used up are flawed in many cases, leading to a fresh contamination after exposure to air with yeasts combined with the native yeast population. Yeasts multiply optimally at $\mathrm{pH} 4.5-6.5$, and are therefore an indicator for bad fermentation and decreased quality.

As expected, approximately two third part of oats samples were in the high risk area for bacterial contamination and $20 \%$ for fungal contamination, while barley and maize showed much lower values. Even $30 \%$ of all concentrate feed, both home mixes and branded products, showed very high levels of bacterial contamination. Total bacterial count normally is an important component of feed evaluation. However, a high bacterial count in feeds of plant origin should be regarded as of secondary importance as the bacteria involved are mainly product-specific so-called yellow bacteria of the family Achromobacteriaceae.

\section{References}

Dresbach O. (2001) In: http://landwirtschaftskammer.com/tierproduktion/heustroh.htm

Meyer H. and Coenen M. (2002): Pferdefütterung, 4th ed., P. Parey Verl. Berlin

Schmidt H.-L. (1985): In: Deutsche tierärztl Wochenschr 92, 205-244

F. J. Schwarz

Department of Animal Science, Division of Animal Nutrition

Technical University of Munich

85350 Freising-Weihenstephan

schwarzf@wzw.tum.de 